\title{
correspondence
}

\section{Soviet Jews}

SIR,-The wave of repressions against Jews seeking permission to emigrate to Israel has recently increased considerably in the USSR.

We scientists, who are being forcibly kept in the USSR against our wills, wish to express our opinion about the present deteriorating situation. We realise that the Soviet authorities now respond to the sympathy and public opinion of the West, and especially of the USA, in terms of what they can gain politically and economically. The Soviet government has found that the West reacts actively to the voices of the persecuted who are deprived of elementary human rights; they therefore try to deprive these people of their voice and to turn them into obedient instruments of Soviet policy.

So the main attack is directed against people whose protests are considered by the authorities to be the most undesirable. Thus Nashpits and Tsitlenok are now charged with participating in a 12-second-long demonstration of protest against the refusal of the Soviet government to issue visas to them. As recently as three years ago such action would have, at the worst, led to 15 days detention for "disturbance of public order".

The other participants in this demonstration were warned that if they set a foot wrong again their fate will be the same as that of Nashpits and Tsitlenok (now sentenced to five years' exile).

The magazine Jews in the USSR, created by Professor Voronel and dedicated to the scientific analysis of different aspects of the cultural life of Jews, was claimed at the trial of the writer Vladimir Maramzin to be against the law and anti-Soviet.

Nowadays, also, participants in the scientific seminar founded by Professor Voronel three years ago are persecuted severely.

- The present leader of the seminar, Mark Azbel, was recently told by the $\mathrm{KGB}$ that the important thing is not that he is a professor of physics, but that he is a lieutenant in the military reserves and subject to call-up for military service. It is ironic that a man aged 43 , who has never been called up, should now, after $2 \frac{1}{2}$ years of waiting for a visa and 3 months in hospital, be needed in the military camps.

- Recently Dr Viktor Brailovskii was called to the KGB where he was threatened with the charge of "insulting a policeman" during a demonstration on February 24. But he was not involved in the demonstration.

- Dr Aleksandr Lunts was warned by the KGB that he can be charged as a traitor to the Motherland.

- In Kharkov unknown persons tried to break into the flat of Professor Leonid Gerber.

- Dr Mikhail Shepelev received seven summonses to military offices and a summons to appear before the police for so-called "parasitism" (being unemployed).

- Eltan Finkelshtein has been called to the military offices again and again. - After being fired from his job, Dr Vainer was ordered to begin work in 15 days. But as it is impossible for a Jewish refusnik to obtain work in his profession, he will have to take a menial job.

- Dr Mikhail Mikylinskii and Dr Eugenir Yakir are charged with parasitism as well, in spite of the fact that they were dismissed from their previous jobs.

So, although nobody has been directly charged for participating in the seminar, it now seems too dangerous to be involved in it. And it is the only means of scientific contact for 8 professors, 24 doctors and 18 bachelors of science from eight cities.

The scientists are persecuted for scientific activities as they were in the Middle Ages. This is the true picture of $\mathrm{KGB}$ activities to stop the voices of Aliya (the movement for the repatriation of Jews to Israel).

It is hard to predict what will happen if the authorities achieve their aim. If protests cease, the government will be able to say that people no longer want to emigrate.

Whether Russian Jews will play a further part in changing the relationship between the USSR and the USA, and whether they will continue to be repressed is an open question; in any case, if their voices are silenced, the Soviet government would be quite free in its suppression of emigration.

We have too few opportunities for preventing such a sequence of events. We do not know how to convince the Soviet authorities that the humane attitude towards emigration is the only possible way in our time.

It is now abundantly clear that the mass attack against Soviet scientists who participate in Professor Mark Azbel's seminar has been instigated by the KGB in preparation for the 250 th anniversary of the Academy of Sciences of the USSR. (The anniversary session was unexpectedly postponed last year because of elections to the Supreme Soviet.)

We are so anxious for scientific contact that we will be happy to speak at and to listen to as many lectures as possible. But such things are impossible, according to KGB logic. So the spirit of the participants in the seminar must be broken before the Anniversary.

We ask all people who are interested in helping the persecuted to help usto raise their voices in defence of emigration, in defence of our natural human rights.

Mark Azbel

VenYAMIN FaIN

ILya PyateTSKII-SHaPIRO

VIKTOR BRAILOVSKY

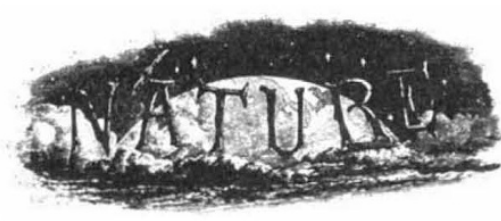

it is

interesting to note that reports from Sweden and Norway state that during the night of March 29-30 last, a heavy rain of ashes or sand took place from the west coast of Norway to the Swedish frontier; the whole of the country was covered with grey dust to such an extent that from a pint of snow more than a tablespoonful of residue was left after the snow had melted. Some chemists of Christiania have examined the ashes, and one of them, Prof. Waage, states that the dust consists of little, irregular, but sharpedged grains, almost all colourlesssome few are of brown colour-and they consist principally of silicates. Acids extract some lime, iron, and alumina from their powder. The professor thinks it likely that the dust originates from an eruption in Iceland. This view is confirmed by a mineral ogical investigation made on another sample of the dust at the Christiania University, by Profs. Kierulf and Fearnley; they recognised the dust to consist of fragments of pumice-stone which is identical with the Hecla pumice-stone. According to Swedish newspapers, some traces of the dustfall were observed even in the vicinitv of Stockholm. Prof. Kierulf also thinks it highly probable that an eruptiin took place in Iceland. The distance from the Iceland volcanoes to the Swedish frontier is about the same as that from Mount Etna to th: Baltic.

from Nature, 11, 515, April 29, 1875. 